\title{
Antibacterial Optimization of Highly Deformed Titanium Alloys for Spinal Implants
}

\author{
Katarzyna Kasperkiewicz ${ }^{1, *(D)}$, Roman Major ${ }^{2, *}$, Anna Sypien ${ }^{2} \oplus$, Marcin Kot $^{3}$, Marcin Dyner ${ }^{4}$, Lukasz Major $^{2}$, \\ Adam Byrski ${ }^{2} \oplus$, Magdalena Kopernik ${ }^{5}$ and Juergen M. Lackner ${ }^{6}$ \\ 1 Institute of Biology, Biotechnology and Environmental Protection, Faculty of Natural Sciences, \\ University of Silesia in Katowice, 40-032 Katowice, Poland \\ 2 Institute of Metallurgy and Materials Science, Polish Academy of Sciences, 30-059 Cracow, Poland; \\ a.sypien@imim.pl (A.S.); l.major@imim.pl (Ł.M.); a.byrski@imim.pl (A.B.) \\ 3 Faculty of Mechanical Engineering and Robotics, AGH University of Science and Technology, \\ 30-059 Cracow, Poland; kotmarc@agh.edu.pl \\ 4 Faculty of Science and Technology, Jan Dlugosz University in Czestochowa, 42-200 Czestochowa, Poland; \\ m.dyner@ajd.czest.pl \\ 5 Faculty of Metals Engineering and Industrial Computer Science, AGH University of Science and Technology, \\ 30-059 Cracow, Poland; kopernik@agh.edu.pl \\ 6 Institute of Surface Technologies and Photonics, Functional Surfaces, \\ Joanneum Research Forschungsges.m.b.H., 8712 Niklasdorf, Austria; juergen.lackner@joanneum.at \\ * Correspondence: katarzyna.kasperkiewicz@us.edu.pl (K.K.); r.major@imim.pl (R.M.)
}

Citation: Kasperkiewicz, K.; Major, R.; Sypien, A.; Kot, M.; Dyner, M.; Major, Ł.; Byrski, A.; Kopernik, M.; Lackner, J.M. Antibacterial Optimization of Highly Deformed Titanium Alloys for Spinal Implants. Molecules 2021, 26, 3145. https:// doi.org/10.3390/molecules26113145

Academic Editor: Bruce P. Lee

Received: 18 April 2021

Accepted: 20 May 2021

Published: 24 May 2021

Publisher's Note: MDPI stays neutral with regard to jurisdictional claims in published maps and institutional affiliations.

Copyright: (c) 2021 by the authors. Licensee MDPI, Basel, Switzerland. This article is an open access article distributed under the terms and conditions of the Creative Commons Attribution (CC BY) license (https:/ / creativecommons.org/licenses/by/ $4.0 /)$.
Abstract: The goal of the work was to develop materials dedicated to spine surgery that minimized the potential for infection originating from the transfer of bacteria during long surgeries. The bacteria form biofilms, causing implant loosening, pain and finally, a risk of paralysis for patients. Our strategy focused both on improvement of antibacterial properties against bacteria adhesion and on wear and corrosion resistance of tools for spine surgery. Further, a $\sim 35 \%$ decrease in implant and tool dimensions was expected by introducing ultrahigh-strength titanium alloys for less-invasive surgeries. The tested materials, in the form of thin, multi-layered coatings, showed nanocrystalline microstructures. Performed direct-cytotoxicity studies (including lactate dehydrogenase activity measurement) showed that there was a low probability of adverse effects on surrounding SAOS-2 (Homo sapiens bone osteosarcoma) cells. The microbiological studies (e.g., ISO 22196 contact tests) showed that implanting $\mathrm{Ag}$ nanoparticles into $\mathrm{Ti} / \mathrm{Ti}_{\mathrm{X}} \mathrm{N}$ coatings inhibited the growth of E. coli and S. aureus cells and reduced their adhesion to the material surface. These findings suggest that Ag-nanoparticles present in implant coatings may potentially minimize infection risk and lower inherent stress.

Keywords: multilayer coatings; antimicrobial materials; biomaterials; Ag nanoparticles; titanium; spinal implants; biofilm; SAOS2; cytotoxicity

\section{Introduction}

Orthopedic spine surgeries are highly challenging interventions with a high risk of neurological damage. In pediatrics (in 3\% of adolescent), the focus is on the orthopedic stabilization of kyphosis and scoliosis, while fusions for osteoporotic vertebrae and spinal tumor resections dominate in the case of elderly patients. The main problems in all orthopedic spine surgeries with screw-rod-plate systems are bacterial surgical site infections (SSI), with rates up to $41.7 \%$ of surgeries in pediatrics (especially in myelodysplasia), resulting in patient morbidity, multiple operations and risks of paralysis. Especially low-vascularized sites around spinal implant surfaces are prone to SSI by Staphylococcus aureus, Staphylococcus epidermidis, Pseudomonas aeruginosa and Propionibacterium acnes. Immediate infection risks have been minimized by surgical techniques, but a reduction in delayed SSIs after a subclinical quiescent period is still a pressing need. They are generally diagnosed in 
late, highly intense stages. A statistical peak for such delayed SSIs occurs 7-8 weeks after surgery. Due to the formation of surface protein layers under physiological conditions, the titanium is highly biocompatible both with cells and bacteria [1-3]. Bacterial adhesion and colonization on titanium implants form biofilms, in which adherent bacteria are protected from host defense systems and bactericidal agents [3-5]. Additionally, local body defense is severely disturbed by surgical trauma in the early phases after implantation as well as compromised on account of a small number of blood vessels in these areas after healing. Consequently, antimicrobial strategies must precede bacterial colonization and be introduced to the most endangered areas at high, but non-cytotoxic, doses.

In the past decades, extensive research and development has been performed on various strategies for antibacterial bone-contacting implant surfaces, including antibioticloaded coatings with Gentamicin (an aminoglycoside) and Vancomycin in porous calcium phosphate, hydroxyapatite, sol-gel and polymer matrices (see overview in [6]). Ceramics (bulk and coatings) are often loaded with drugs through physical absorption obtained by dipping or immersion, which results in burst release in less than one hour $[7,8]$. Covalent bonded antibiotics decrease the drug release rate or provide antibacterial protection in direct contact with bacteria $[9,10]$. Further, sol-gel and bio-resorbable polymer coatings (Polylactic acid-PLA, Polyglycolic acid-PGA, Polyethylene glycol-PEG) are useful for achieving slower release rates [11]. Nanopore and nanotube surfaces enable antibiotic drug loading (e.g., by infiltration or lyophilization) and merge it with high osteoconductivity for improved bone integration, but they all struggle with too-high drug release rates [12,13]. In conclusion, long-term antibiotic delivery at effective concentrations (above the minimum for preventing formation of bacterial resistance and below the cytotoxicity threshold) is a challenging problem, requiring a novel approach like the hybrid materials concept.

Alternatives with a lower risk of drug resistance to antibiotics, but weighted with an eventual danger of in vivo cell damage [3,14], are coatings containing non-antibiotic organic agents (e.g., chlorhexidine/chloroxylenol adsorbed in titania $[15,16])$. The moststudied surfaces are, by far, those based on cation-functionalized polymers such as quaternary polyethylenimines (QPEIs) or polymers with cationic quaternary ammonium salts (QAS) $[17,18]$. Quorum-sensing (QS) inhibitors and peptides are also intensively studied, but of interest are only those with low antimicrobial activity against a broad spectrum of biological species and the tendency to develop drug resistance $[19,20]$. In contrast, non-antibiotic, inorganic Ag has a broad antibacterial spectrum at very low ppb (parts per billion) concentrations in tissue [21-25]. It inhibits bacterial adhesion [26], as well as having both a long-lasting effect and low cytotoxicity at necessary doses [27], backed by very low risk of resistance development to bacteria. Beyond others, Ag, Ti-Ag [24], TiN-Ag [28,29], TiN-Ag [30,31], Ag-DLC [32,33], and Ti-Mg-Ag(Pt) [34] coatings are presently in development, or, i.e., under clinical study. Numerous techniques of incorporating Ag nanoparticles into coatings are being examined: e.g., radio-frequency magnetron sputter-deposition [35]. The drawback of $\mathrm{Ag}$ is its release kinetics to surrounding tissue, which is electrochemically dependent on the $\mathrm{pH}$ value and may be too low to counteract bacteria colonization in the injured surrounding tissue.

Resistance to bacterial adhesion can be found also in other coatings; i.e., $\mathrm{TiO}_{2}$ in combination with UV light may photocatalyze hydrocarbons and bacteria [36], or $\mathrm{TiNO}_{\mathrm{x}}$, with especially $\sim 104 \mu \Omega \mathrm{cm}$ electrical resistance, minimizes bacterial adhesion, too [37]. The same effect could be achieved with protein-resistant poly(methacrylic acid) and poly(ethylene glycol) $[23,38]$, which both significantly reduce bacterial adhesion (e.g., brush-like 2D structure pattern of PEG), but hinder osteoblast adhesion. In contrast, bio-active chitosan and hyaluronic acid may stimulate differentiation of osteoprogenitor cells [39,40]. Finally, nitric oxide (NO) release from sol-gel coatings acts anti-microbial in vitro [41]. Nevertheless, all these films have low mechanical stability and adhesion due to grafting to Ti by linking molecules $[40,42]$ or embedding the bioactive molecules in layer-by-layer self-assembled coatings. 
Finally, bacterial adhesion is dependent on the protein layer on the biomaterial surface on which fibrinogen is counted as one of the major plasma proteins. As well as fibronectin, mainly involved in blood clotting due to the adhesion of S. aureus and E. coli [43-45], while adsorbed albumin on Ti implants drastically reduces S. aureus and P. aeruginosa adhesion [46]. In contrast, S. epidermidis adheres and colonizes surfaces using a selfgenerated, viscous biofilm composed of polysaccharides [47], demanding anti-adhesive, hydrophobic surface properties of biomaterials.

The use of silver in coatings may seems to be a standard approach in the case of materials presenting antibacterial properties. However, one of the main problems associated with biocompatibility and biotolerance is the toxicity to human tissues of the materials concerned and the reaction of the immune system. In some cases, the problem is so specific that it manifests itself as a strong allergic reaction. Silver nanoparticles are generally considered to be useful antibacterial agents. even as their use must be always carefully monitored. Therefore, in the present work, it has been decided to use them as a coating enhancer, only.

An ultrafine $(<1 \mu \mathrm{m})$ or even nanocrystalline $(<100 \mathrm{~nm})$ material prepared by a severe plastic deformation (SPD) process is characterized by very high strength, which allows for lightening the implants. SPD is a metal forming process in which a metal is subjected to an ultrahigh plastic strain in order to refine its grain structure increasing both its strength and ductility. The dominating SPD technique is equal channel angular pressing (ECAP), which enables up-scaling the SPD to an industrial-applicable size. During ECAP processing, the raw material is pressed through a die, with a channel bent at a predetermined angle (usually $90^{\circ}$ or $120^{\circ}$ ). ECAP process enables introducing a large amount of simple shear deformation to enhance hydrostatic pressure in single or multiple processing steps without changing the cross-section of the work piece. Due to this large plastic deformation, ECAP processing of Ti and Ti alloys has resulted in an UFG (ultrafine-grained) structure with a high defect density (dislocations, grain boundaries) and correspondingly increased strength. That is why the titanium alloys which undergo SPD should be a material of choice for products as demanding as spine implants.

The goal of the work was to elaborate multilayer coatings dedicated to spine implants with microstructures ensuring both low cytotoxicity and microbiological impact.

\section{Results}

\subsection{Fatigue Properties of the Strengthened Substrate}

Fatigue properties of CP-Ti (commercially pure titanium) and Ti64, under conventional and ECAP heat treatment, were investigated. Plastic-strain-controlled low-cycle fatigue (LCF) tests-according to ASTM E606-in the range of $10^{3}$ to $10^{5}(1000-100,000)$ cycles at a constant plastic strain rate of $1 \times 10^{-3} \mathrm{~s}^{-1}$ and at variable frequencies $(\mathrm{f}=0.05-0.906 \mathrm{~Hz})$ were performed. Additionally, stress-controlled high-cycle fatigue (HCF) testing (according to ASTM E466) in the range of $10^{5}-10^{7}(100,000-10,000,000)$ cycles at a constant frequency $(\mathrm{f}=10 \mathrm{~Hz})$ was carried out. Manufacturing of special fatigue samples was ordered at Westmoreland Mechanical Testing \& Research, Ltd.

\subsection{Microstructure Analysis of the Smart Bioactive Coating}

The coatings were applied on both the CP-Ti and austenitic steel substrates. They differed in their content of Ag nanoparticles and thickness. The detailed microstructure characteristics were carried out on the thickest coating $(\sim 3.80 \mu \mathrm{m})$ containing the largest amount of Ag nanoparticles, which allowed the best description of this type of structure (Figure 1A). 

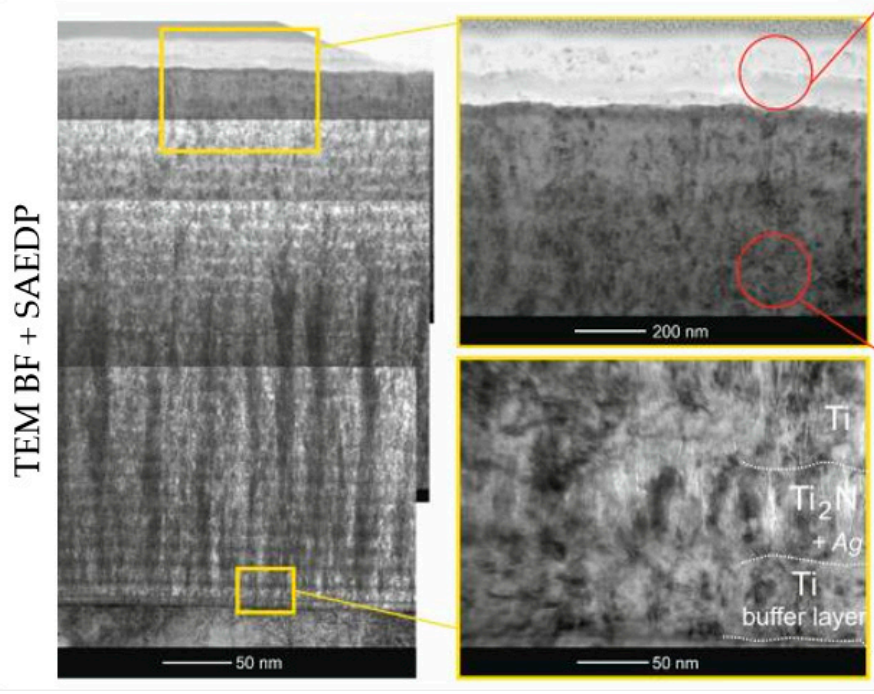

(A)

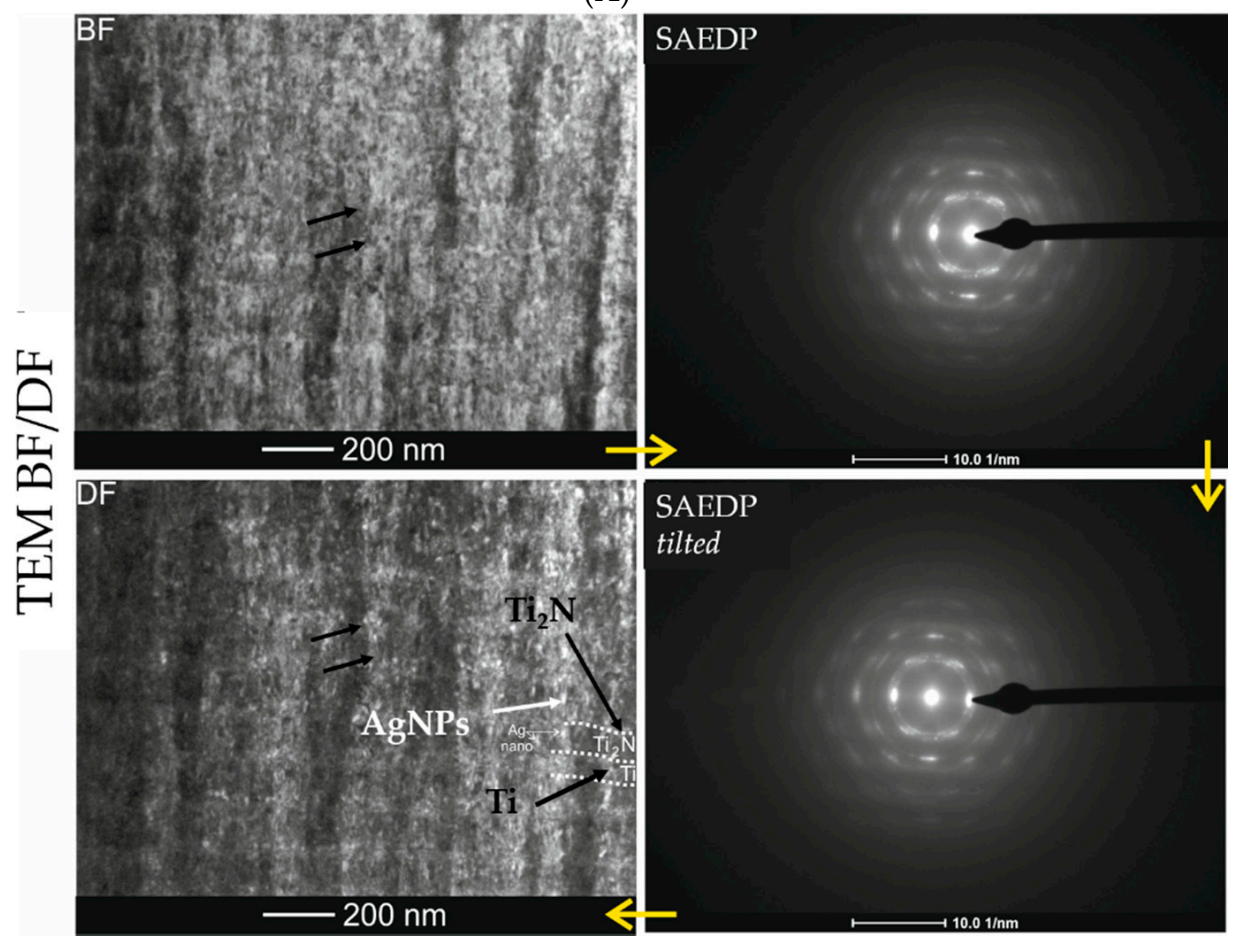

(B)

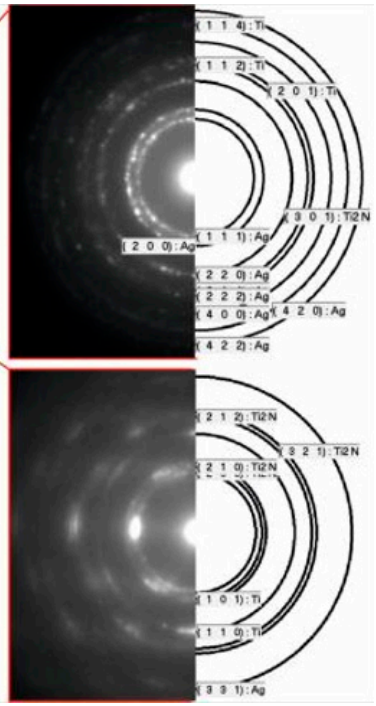


The presence of nanoparticles in the $\mathrm{Ti} / \mathrm{Ti}_{2} \mathrm{~N}$ structure was independently confirmed by high resolution TEM (HRTEM: high-resolution transmission electron microscopy) observations (Figure 2).
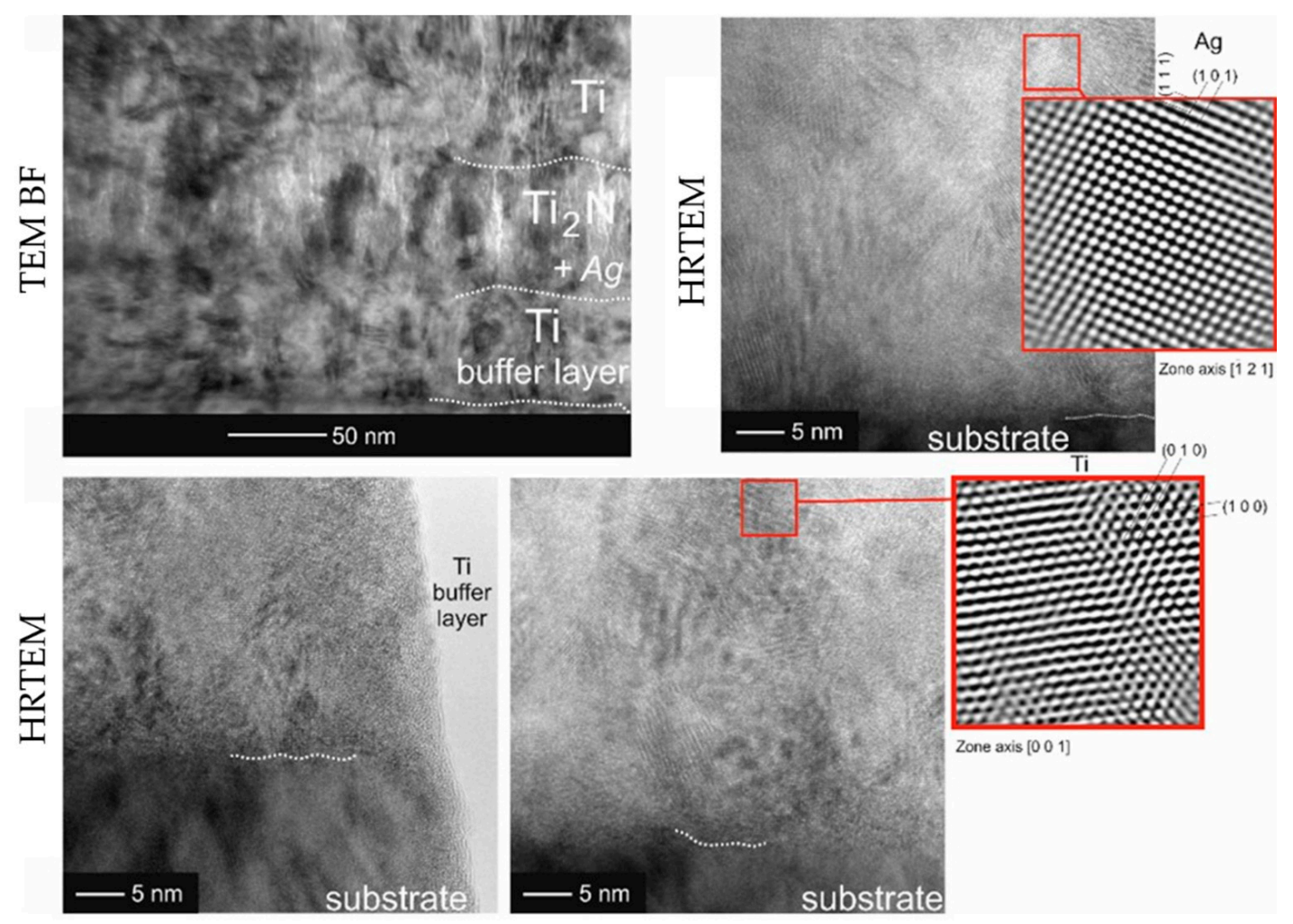

(A)

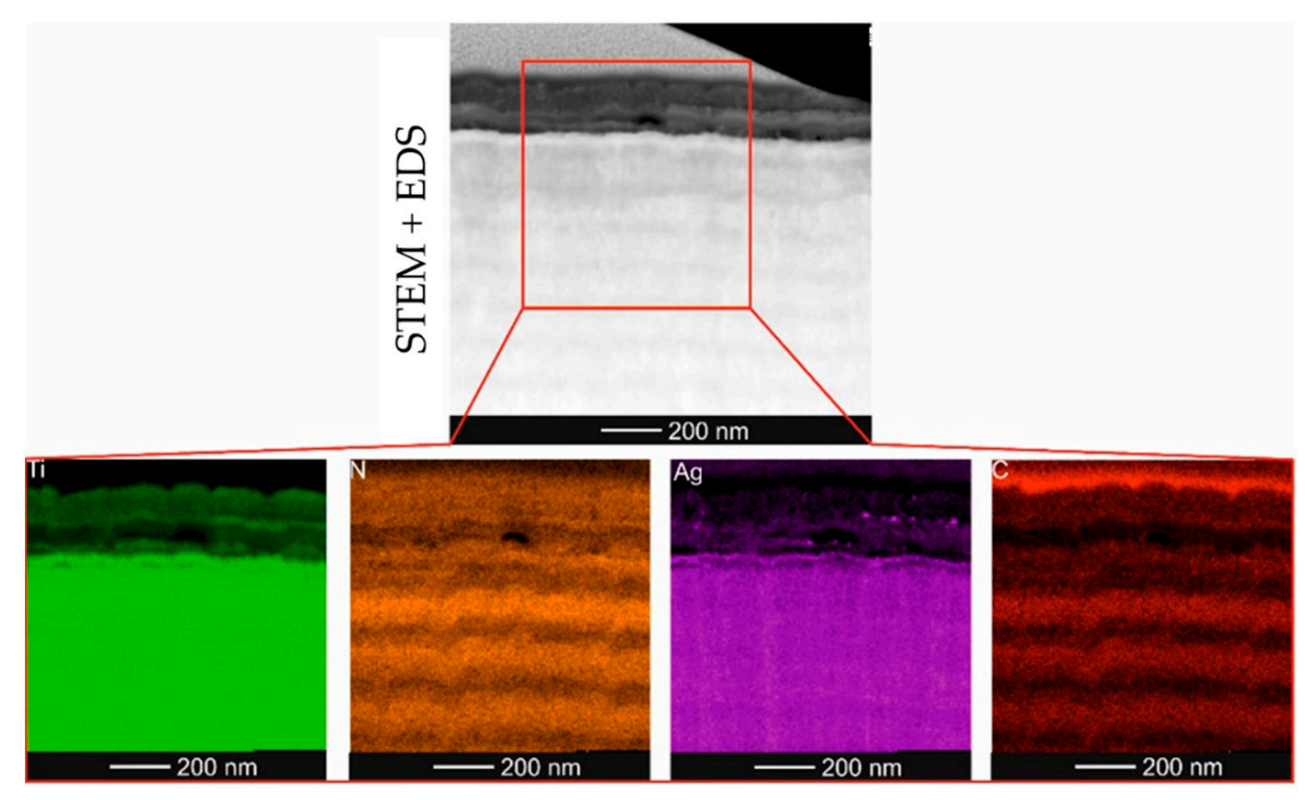

(B)

Figure 2. Cont. 


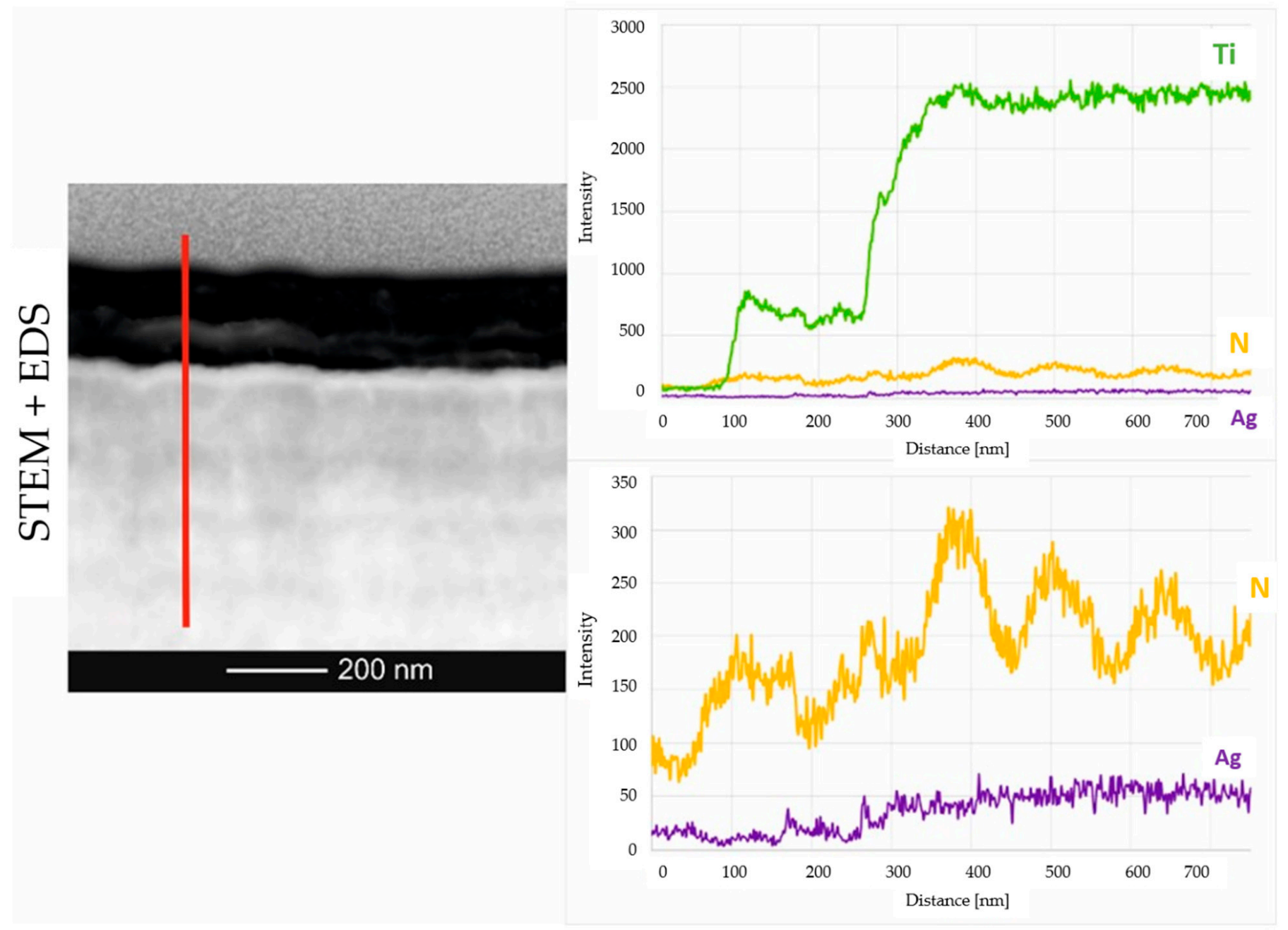

(C)

Figure 2. TEM/BF and HREM images of distribution of Ag nanocrystallites in $\mathrm{Ti} / \mathrm{Ti}_{2} \mathrm{~N}$ multilayer (A), STEM image and accompanying maps presenting distribution of Ti, N, Ag, C elements from area marked with square (B) and profiles of chemical composition across the multilayer (along the marked line) (C).

Qualitative analysis of the chemical composition was carried out by means of X-ray energy dispersive spectroscopy (EDS) from the area marked with red square (Figure 2A) and along the line, perpendicular to the coating/substrate boundary (Figure 2B). The performed measurements indicated that the presence of lighter mass-thickness contrast at the near-surface area was associated with a much lower content of both titanium and silver.

\subsection{Mechanical Properties}

The tests were carried out for up to 2000 cycles. The wear rate was calculated according to the recommendations of ISO 20,808 from dependencies:

$$
W=\frac{V}{F_{n} \cdot S}
$$

In the formula, $W$ is the wear indicator in $\mathrm{mm}^{3} \cdot \mathrm{N}^{-1} \mathrm{~m}^{-1}, V$ is the volume of the material removed, $F_{n}$ is the normal load and $S$ is the overcome friction path.

The coefficients of the friction and wear indicators were determined according to ISO standard 20808:2016. Tests of the friction coefficients and wear indicators were performed based on ISO 20808:2016 (Table 1). 
Table 1. Results of friction coefficient and wear indicator tests.

\begin{tabular}{ccc}
\hline Layer & $\begin{array}{c}\text { Wear Rate } \\
\boldsymbol{F}=\mathbf{0 . 5} \mathbf{~ N} \\
\mathbf{N = \mathbf { 2 0 0 0 }} \times \mathbf{1 0}\end{array}$ & Friction Coefficient \\
\hline $\mathrm{Ti} / \mathrm{TiN}+5 \% \mathrm{Ag}$ & 251.7 & 0.428 \\
$\mathrm{Ti} / \mathrm{TiN}+7.5 \% \mathrm{Ag}$ & 564.8 & 0.494 \\
$\mathrm{Ti} / \mathrm{TiN}+10 \% \mathrm{Ag}$ & 574.1 & 0.478 \\
$\mathrm{Ti} / \mathrm{TiN}+15 \% \mathrm{Ag}$ & 835.7 & 0.404 \\
\hline
\end{tabular}

\subsection{Direct Cytotoxicity Analysis}

Direct cytotoxicity tests were conducted for $\mathrm{Ti} / \mathrm{Ti}_{x} \mathrm{~N}$ materials implanted with $\mathrm{Ag}$ nanoparticles. The results of the tested materials are shown in Figure 3. As a reference, a glass plate was taken.

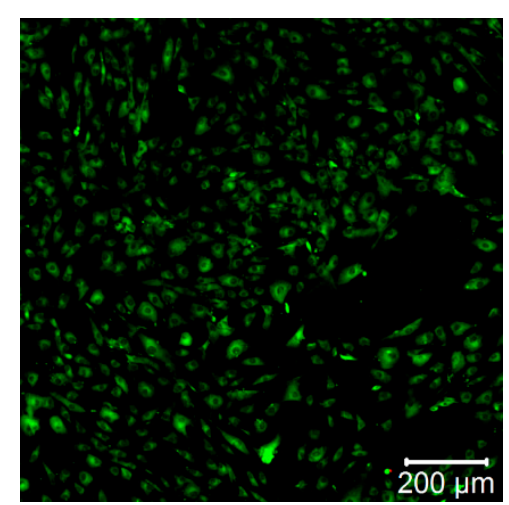

(A)

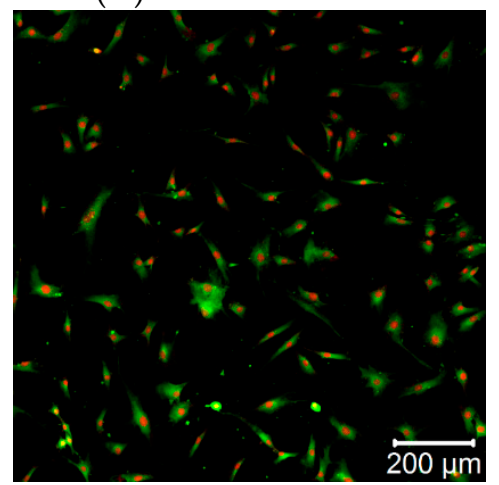

(D)

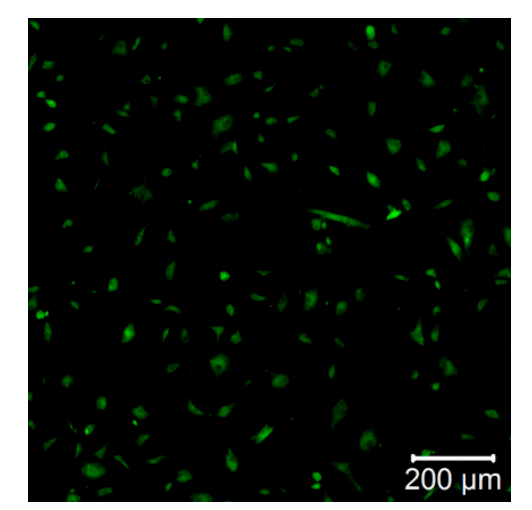

(B)

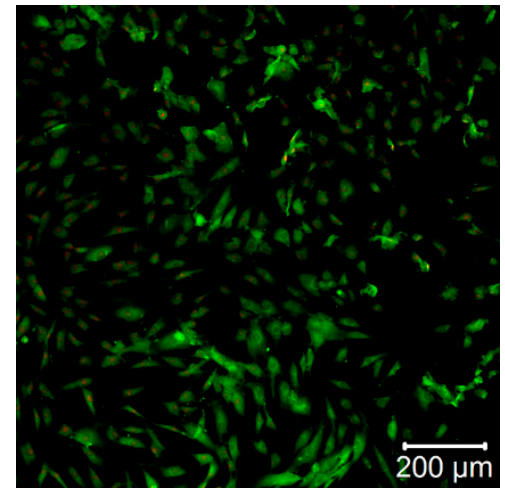

(C)

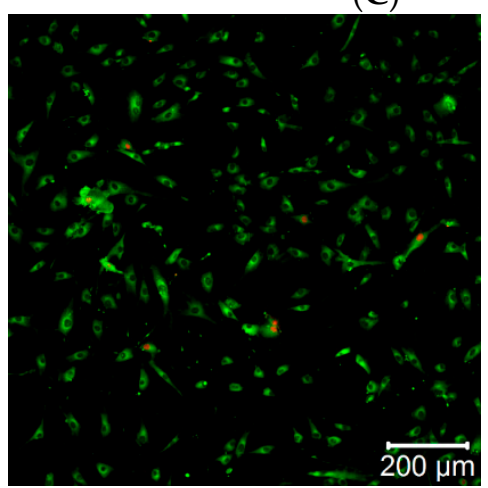

(E)

Figure 3. Images from confocal microscope of: (A) reference, (B) $\mathrm{Ti} / \mathrm{TiN}+5 \% \mathrm{Ag}$, (C) $\mathrm{Ti} / \mathrm{TiN}+7.5 \% \mathrm{Ag}$, (D) $\mathrm{Ti} / \mathrm{TiN}+10 \%$ $\mathrm{Ag},(\mathbf{E}) \mathrm{Ti} / \mathrm{TiN}+15 \% \mathrm{Ag}$.

The obtained results (Figure 3A-E) document a relatively good cell survival rate on the surface. Compared to the reference material (Figure 3A), the most necrotic cells were found for $\mathrm{Ti} / \mathrm{TiN}+10 \% \mathrm{Ag}$ (Figure 3D). This is shown by the increased number of red spots on the image, which correspond to the excitation of propidium iodide (PI), which marks necrotic cells. High concentrations of Ag nanoparticles lead to the formation of Ag aggregates, resulting in lowering the concentration of biologically active Ag nanoparticles. It indicates that a higher concentration of nanoparticles may show lower cytotoxicity (Figure 3E) [48]. No increased number of necrotic cells was found for the Ti/TiN + 5\% Ag coating (Figure 3B). However, this material was not conducive for their growth. For Ti/TiN $+7.5 \% \mathrm{Ag}$ (Figure 3C) and Ti/ TiN + 15\% Ag (Figure 3E), a large number of cells with active mitochondria and low mortality of cells were found. This proves good biological properties of the tested materials. 


\subsection{Lactate Dehydrogenase}

In order to evaluate the cytotoxicity of examined coatings, the extracellular lactate dehydrogenase activity of the SAOS-2 cell line was measured. Results are shown in Figure 4 .

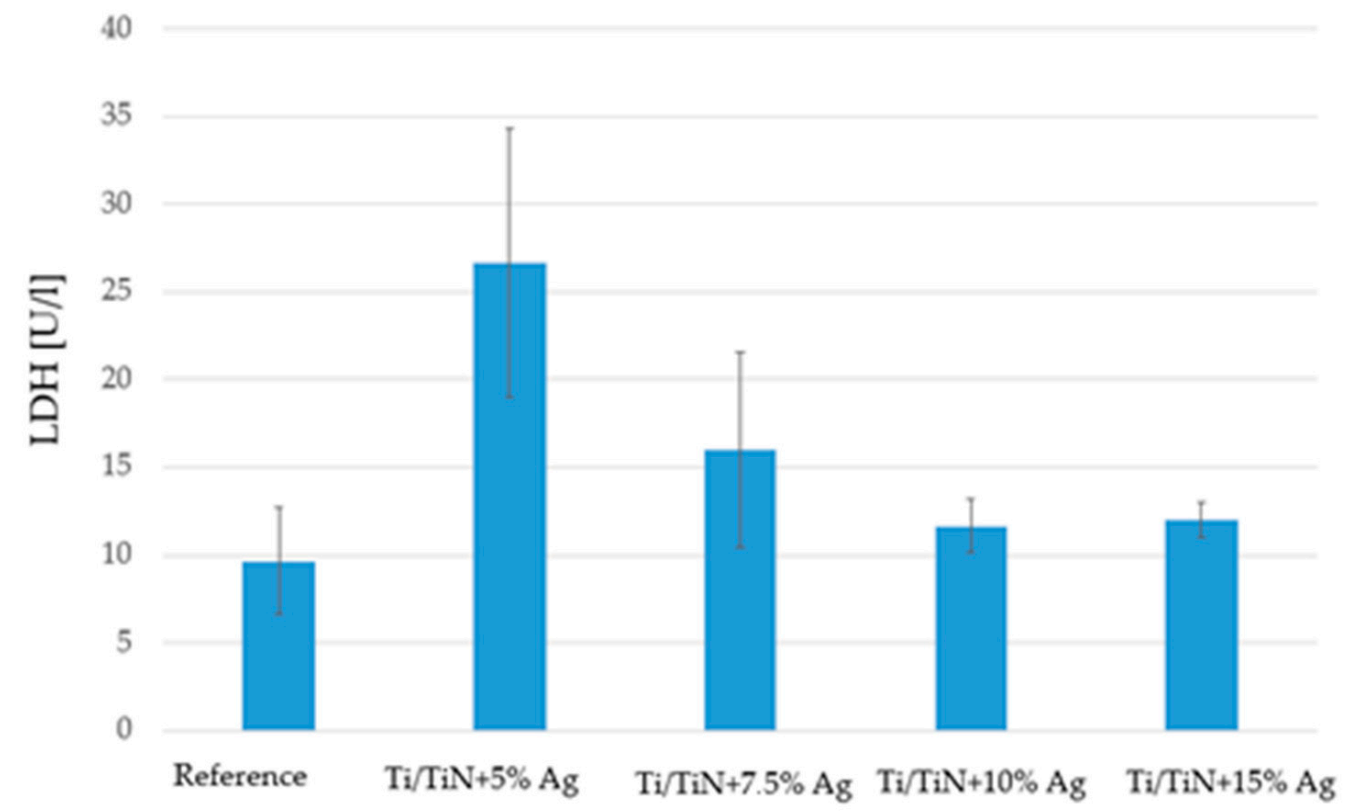

Figure 4. Results of cytotoxicity tests using lactate dehydrogenase $(n=5 \pm \operatorname{SD})$.

The results (presented as the average of five independent iterations) of cytotoxicity tests using the lactate dehydrogenase method showed the worst properties for Ti/TiN + $5 \%$ Ag coatings. As the silver content in the coating structure increased, improved coating properties were observed. This was manifested by a reduced risk of destructive effects of the materials on the surrounding cells.

\subsection{Surface Interaction of Coatings with Selected Strains of Bacteria and Fungi}

\subsubsection{Growth, Adhesion and Bacterial Biofilm Formation on the Surface of Biomaterials}

The biomaterials under examination were incubated with cultivation of Pseudomonas aeruginosa, Streptococcus pyogenes and Candida albicans, and an increase in OD600 (optical density) levels was observed for Streptococcus pyogenes and Candida albicans in cultivation with the tested biomaterials. This may have indirectly indicated the growth of microorganisms during the incubation as well as implied that the biomaterials had neither bactericidal nor bacteriostatic properties. Bacterial adhesion on the tested surface was observed using the SEM (scanning electron microscopy) technique. The results are presented in Figure 5.

Adhesion of single bacterial cells in the shape of small, short rods was observed on the surface of tested materials. Cells of Pseudomonas aeruginosa formed loose clusters (Figure 5A). No formation of biofilm structure by this microorganism was observed. On the surface of the tested material (Figure 5B), few spherical cells forming characteristic chains were visible. Bacterial adhesion on this material was very low. The adhesion of numerous Candida albicans cell was observed on the surface on the tested material (Figure 5C). Spherical cells (typical for these microorganisms) as well as pili forms (elongated structures of varying length and branched structures composed of pudding cells) were visible. The filamentous cells presented the structure of pseudomycellium (Figure 5C). 


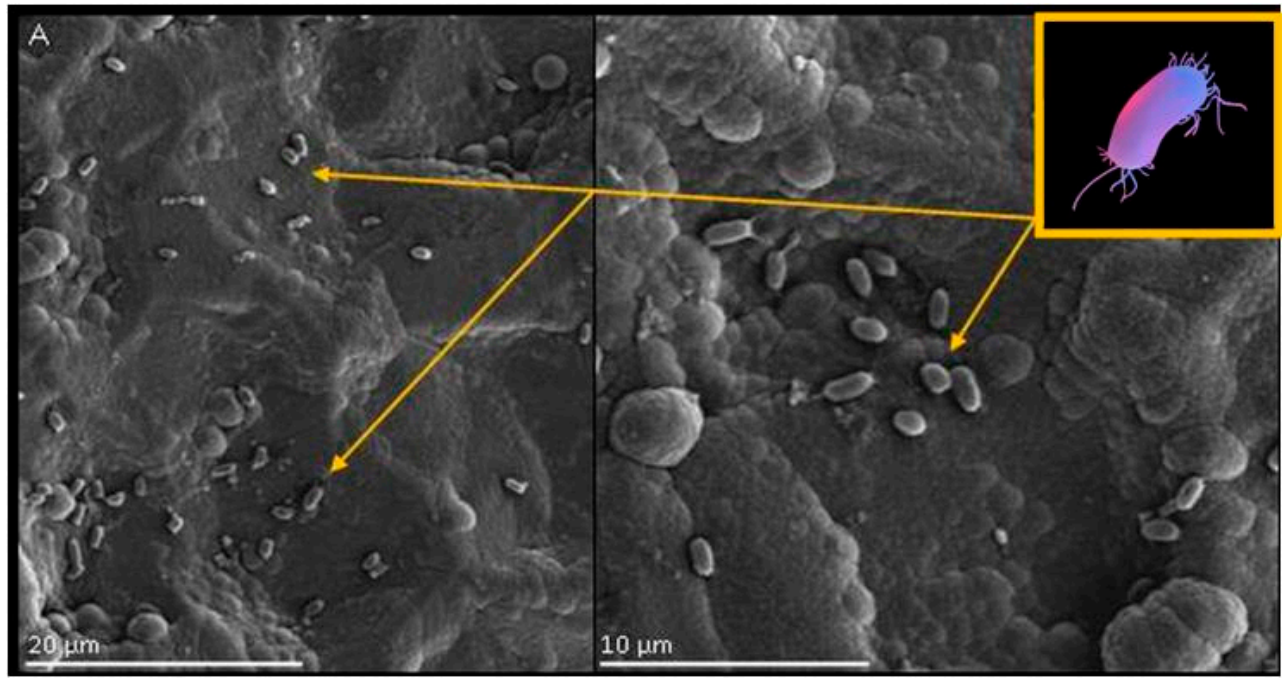

(A)

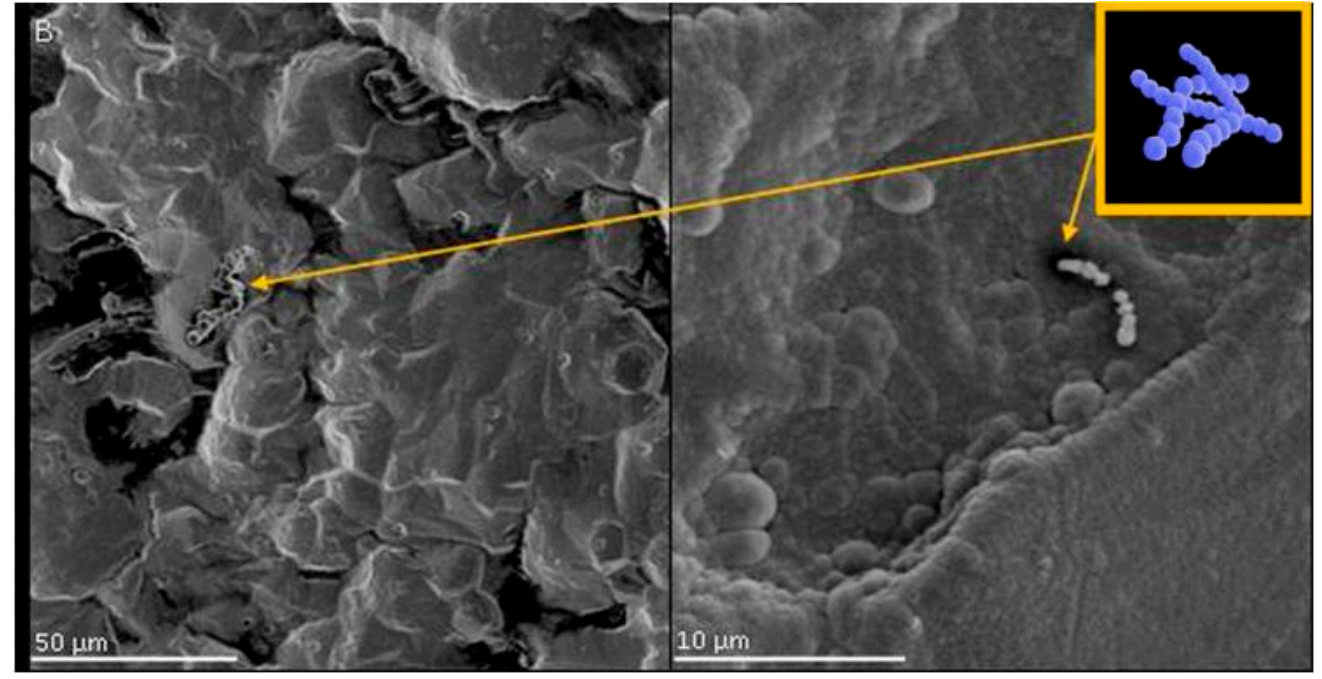

(B)

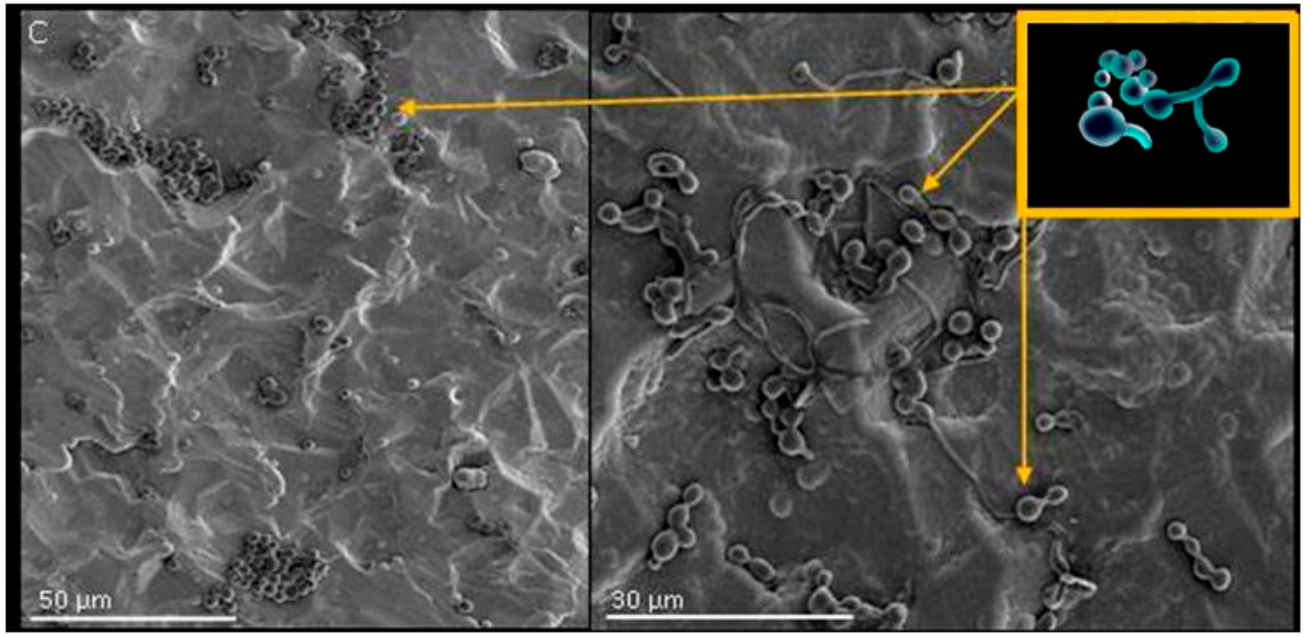

(C)

Figure 5. Colonization of the tested biomaterial ( $\mathrm{Ti} / \mathrm{TiN}+7.5 \% \mathrm{Ag}$ ) by microorganisms (bacteria and fungi). Surface morphology (SEM) with the: (A) Pseudomonas aeruginosa, (B) Streptococcus pyogenes, (C) Candida albicans. 


\subsubsection{Tests of Viability of Microorganisms on the Tested Biomaterials}

The study aimed to determine the cytotoxic activity of biomaterials based on cell membrane integrity analysis because all permanent damage to the cell membrane leads to bacterial cell death [49]. In the test used to determine changes in cell integrity, the cells of the Pseudomonas aeruginosa bacterium were incubated with a positive charge dye solution (fluorescent propidium iodide). The results are presented in Figure 6.

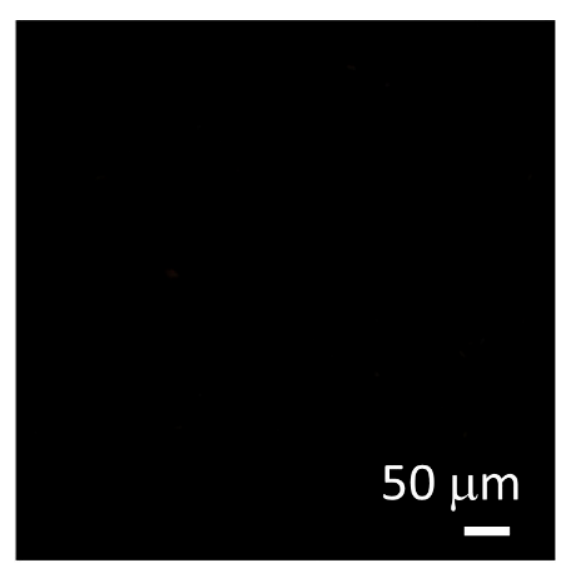

(A)

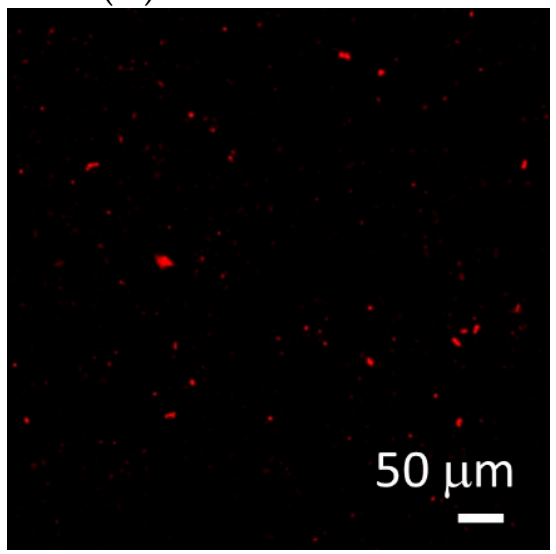

(D)

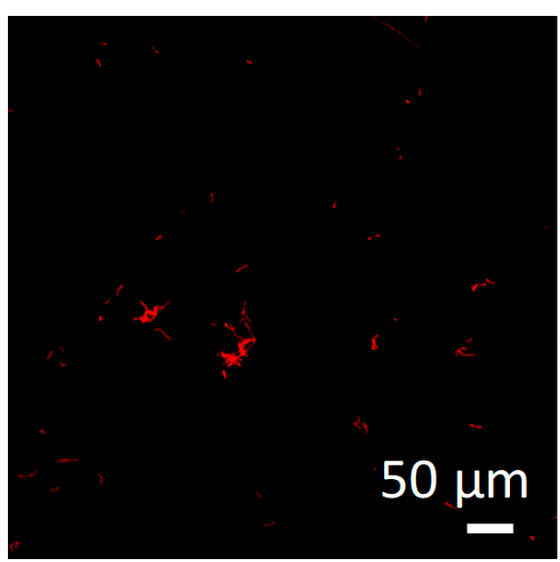

(B)

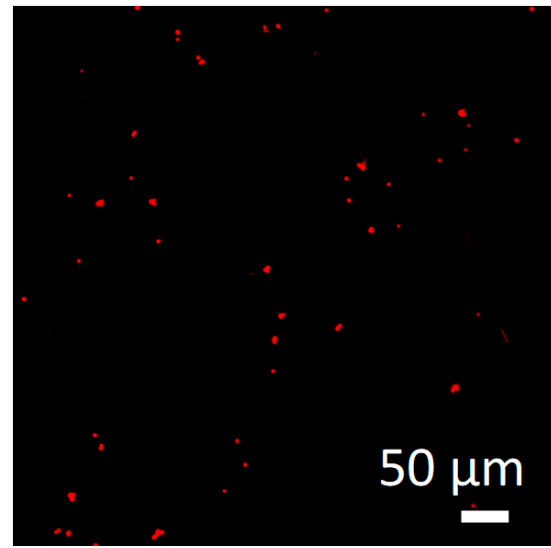

(C)

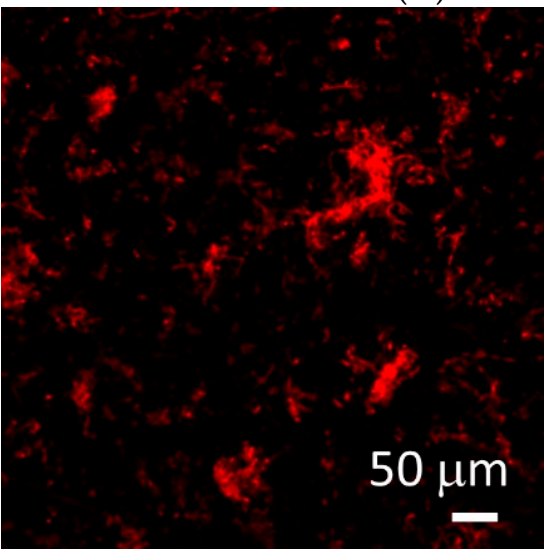

(E)

Figure 6. The viability of bacteria on the surface of the tested biomaterials. (A) Reference substrate, $(\mathbf{B}) \mathrm{Ti} / \mathrm{TiN}+5 \% \mathrm{Ag}$, (C) $\mathrm{Ti} / \mathrm{TiN}+7.5 \% \mathrm{Ag}$, (D) $\mathrm{Ti} / \mathrm{TiN}+10 \% \mathrm{Ag}$, (E) $\mathrm{Ti} / \mathrm{TiN}+15 \% \mathrm{Ag}$.

For the bacterium Pseudomonas aeruginosa, a large number of dead bacterial cells for the $\mathrm{Ti} / \mathrm{TiN}+15 \%$ Ag coating were found in the tested cultures with the biomaterials, which confirmed its bactericidal properties (Figure 6E). In comparison with the results of direct cytotoxicity, the presently obtained results are proof of the very good antibacterial properties of this material.

\subsubsection{Test of Antimicrobial Activity of Biomaterials According to ISO 22196}

In order to determine the antimicrobial activity of a material, the difference in microorganism growth on treated and untreated surfaces was determined. The numbers of recovered bacteria cells (S. aureus) from each specimen are shown in Figure 7.

Diversity in the number of recovered Staphylococcus aureus cells after $24 \mathrm{~h}$ of incubation was observed. The highest number $\left(10^{6} \mathrm{CFU}\right.$ (Colony Forming Units)) of viable cells were obtained from untreated samples. Both $\mathrm{Ti} / \mathrm{TiN}+7.5 \% \mathrm{Ag}$ and $\mathrm{Ti} / \mathrm{TiN}+10 \% \mathrm{Ag}$ showed moderate bacteriostatic activity, whereas $\mathrm{Ti} / \mathrm{TiN}+15 \% \mathrm{Ag}$ and $\mathrm{Ti} / \mathrm{TiN}+5 \% \mathrm{Ag}$ showed bactericidal activity-no viable $S$. aureus cells were recovered from specimens. Due to the Log scale, the standard deviation for $\mathrm{Ti} / \mathrm{TiN}+10 \%$ was quite small. 


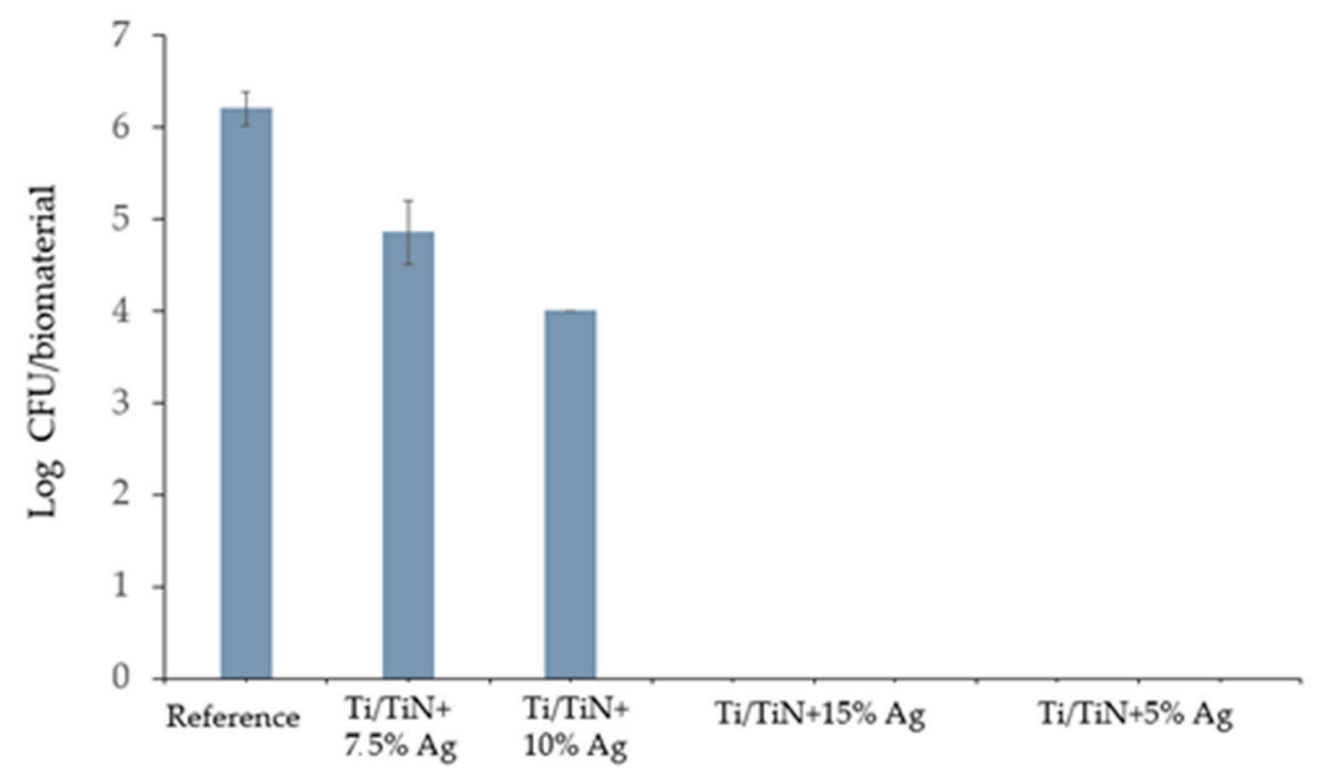

Figure 7. Number of recovered S. aureus cells from each surface after 24 h contact test ( $n=4 \pm$ SD).

Material yields antibacterial properties if the obtained $\mathrm{R}$ value is greater than 2, as stated in ISO 22196. Every tested biomaterial beyond $\mathrm{Ti} / \mathrm{TiN}+7.5 \% \mathrm{Ag}$ showed antibacterial activity against Gram-positive Staphylococcus aureus. Furthermore, the greatest Log reduction (6 orders of magnitude) for $\mathrm{Ti} / \mathrm{TiN}+15 \% \mathrm{Ag}$ and $\mathrm{Ti} / \mathrm{TiN}+5 \% \mathrm{Ag}$ compared to untreated specimens was observed.

\section{Discussion}

The present experiment covered deposition of multi-layer $\mathrm{Ti} / \mathrm{Ti}_{\mathrm{x}} \mathrm{N}$ coatings implanted with Ag nanoparticles and their detailed microstructural characteristics. This multilayer coating was elaborated with the aim of increasing not only the mechanical properties of the surface, but also its antibacterial properties. The performed investigations using the TEM method showed an even distribution of nanoparticles in the multilayer structure. Various mechanical tests allowed for selecting the coating presenting the highest wear resistance. On the basis of the results obtained from the experiments with the first group of coatings produced on spinal implants, an improved series of coatings on spinal implants was produced. They were built from two parts; i.e., the first one from the substrate was made of a $\mathrm{Ti} / \mathrm{Ti}_{2} \mathrm{~N}$ multi-layer implanted with $7.5 \%$ at. $\mathrm{Ag}$, while the second was based on a-C:H implanted with 3 and $7 \%$ at. Ag and 5\% at. Si. The presence of nanoparticles in the a-C:H part was associated not only with increasing the antimicrobial properties of coatings, but also with lowering the inherent stress.

The improvement in mechanical properties resulting in improved microbiological properties most likely resulted from the elimination of structural defects by anchoring silver nanoparticles. The magnetron method is an application technique based on the physical impingement of disc particles in a protective atmosphere. Diffusion does not occur in this technique; it is only considerable as a pseudo-diffusion phenomenon.

The antimicrobial properties of $\mathrm{Ti} / \mathrm{Ti}_{\mathrm{x}} \mathrm{N}$ coatings implanted with Ag nanoparticles were tested according to the ISO 22,196 norm. This norm is widely utilized in biomaterial engineering as a simple and reliable means of verifying anti-pathogenic properties of surfaces.

Staphylococcus aureus and Escherichia coli are responsible for most implant-related infections; therefore, usage of these bacteria in experiments is justified, similar to results presented elsewhere [50]. Bacterial infection is always established with adhesion of the cell to the surface of tissue or biomaterial, followed by bacterial growth and biofilm formation. Inhibiting infection during one of those steps prevents spreading of the SSI and decreases coating bio-corrosion. Ag nanoparticles are known for their antibacterial properties, and 
several mechanisms have been raised. In particular, they generate reactive oxygen species that may disrupt cell wall synthesis, inhibit enzymes and corrupt DNA replication. Thereby, biomaterials which release Ag nanoparticles may significantly reduce the number of bacteria adhering to a surface and prevent them from growing and spreading further [51]. Carried-out tests indicate that specimens $\mathrm{Ti} / \mathrm{TiN}+15 \% \mathrm{Ag}$ and $\mathrm{Ti} / \mathrm{TiN}+5 \% \mathrm{Ag}$ stand out in their bacteria contact-killing properties $(R$ index $=6.2)$; however, the Ti/TiN $+10 \%$ Ag specimen showed significantly lower antimicrobial activity $(R$ index $=2.2)$, although it was still higher than 2.0 and likewise may have been effective. The $\mathrm{Ti} / \mathrm{TiN}+7.5 \% \mathrm{Ag}$ material showed only limited antibacterial properties $(R$ index $=1.3)$. Results were partially unexpected because a higher concentration of $\mathrm{Ag}$ nanoparticles should result in greater $S$. aureus growth inhibition, and thus a higher $R$ value [52]. As mentioned above, it could be caused by aggregation of Ag nanoparticles [48] or development of nanosilver resistance mechanisms in bacteria [53].

\section{Materials and Methods}

\subsection{Substrate Preparation}

In the work for the substrate, CP-Ti grade 4 was used. In order to fragment the structure, an extrusion in the angle channel was used, or so-called equal channel angular pressing. The process parameters of ECAP were optimized in order to reduce the number of passes needed to achieve proper mechanical properties and cost effectiveness. Up to 24 ECAP passes were carried out, and the mechanical properties were estimated. As part of post-processing, thermal treatments were performed. To further improve the mechanical properties of ECAP processing, thermal treatments were carried out. Regimes for thermal treatments and dwell times were as follows: $150-350^{\circ} \mathrm{C}$ and $0.5-20 \mathrm{~h}$, respectively. The plastic working and postprocessing were intended to homogenize the structures and properties. As the final substrate material, a fine-grained anisotropic material was used.

\subsection{Smart Bioactive Coatings to Control Biological Interaction}

The deposition of the coatings was performed by physical and plasma-enhanced chemical vapor deposition (PVD and PECVD, respectively) on the SPD-strengthened Ti alloys. Prior to the deposition, all substrates were polished, cleaned ultrasonically in alcohol and dried in a vacuum. The manipulation of the substrates occurred under clean room conditions to prevent any dust deposits on the surfaces. After mounting the substrates in the vacuum deposition chamber (Leybold Oerlikon, Cologne, Germany) (horizontally positioned at $\sim 100 \mathrm{~mm}$ distance to the coating sources), the chamber was evacuated to a $2 \times 10^{-5}$ mbar starting pressure. Prior to the deposition, a final cleaning and activation of the polymer surfaces occurred by applying the $\mathrm{Ar}-\mathrm{O}_{2}$ plasma of a linear anode layer ion source. All tested materials are listed in Table 1. Magnetron sputtering was applied right after ion source-based plasma cleaning and activation. Sputtering from pure pyrolytic carbon target materials (Schunk, Vienna, Austria) occurred in an $\mathrm{N}_{2}+\mathrm{Ar}$ atmosphere to obtain titanium nitride coatings. All used gases were of $5 \mathrm{~N}$ purity. Various deposition times helped to obtain different thicknesses. Three types of coatings differing in the nanoparticle contents of the outer a-C:H part of the coating were produced (Table 2).

Table 2. The list of coatings used in experiments.

\begin{tabular}{ccc}
\hline L.P. & Layer & Thickness $[\boldsymbol{\mu m}]$ \\
\hline 1 & $\mathrm{Ti} / \mathrm{TiN} 1: 1$ doped $5 \% \mathrm{Ag}$ & 3.40 \\
2 & $\mathrm{Ti} / \mathrm{TiN} 1: 1$ doped $7.5 \% \mathrm{Ag}$ & 3.40 \\
3 & $\mathrm{Ti} / \mathrm{TiN} 1: 1$ doped $10 \% \mathrm{Ag}$ & 2.70 \\
4 & $\mathrm{Ti} / \mathrm{TiN} 1: 1$ doped $15 \% \mathrm{Ag}$ & 3.50 \\
\hline
\end{tabular}

\subsubsection{Microstructure}

Microstructure characterization was carried out using scanning and transmission electron microscopy (SEM and TEM, respectively) as described in detail elsewhere [54]. 
It was performed with the help of a FEI Quanta 3D FEG Scanning Electron Microscope and a Tecnai G2 F20 $(200 \mathrm{kV})$ FEG, located in the Accredited Testing Laboratories at the IMMS, PAS.

\subsubsection{Mechanical Properties of the Thin Films}

The mechanical properties were estimated by measuring the micro-hardness by applying the scratch test and the wear test at the contact point of the shield. The method was similar to one described elsewhere $[55,56]$. Indentation tests were carried out at loads of $2 \mathrm{mN}$ and $5 \mathrm{mN}$ and accompanying growth and deceleration speeds of $4 \mathrm{mN} / \mathrm{min}$ and $10 \mathrm{mN} / \mathrm{min}$. A diamond indenter with Berkovich geometry was used for testing. Scratch tests were performed using a Rockwell C indenter with a radius of $200 \mu \mathrm{m}$. The length of the scratch test was $5 \mathrm{~mm}$, and the indentation rate was $5 \mathrm{mN} / \mathrm{min}$. The load range for all coatings was $0-30 \mathrm{~N}$. Tribological tests (for wear) were made at the sphere-shield interface. The ball was made of $\mathrm{Al}_{2} \mathrm{O}_{3}$ with diameter $d=6 \mathrm{~mm}$. Tests were made at $1 \mathrm{~N}$ load. The rotational speed was $120 \mathrm{rpm}$.

\subsubsection{Cytotoxicity}

The investigations were based on direct cytotoxicity tests. The Homo sapiens bone osteosarcoma cell line (SAOS-2) was chosen because it could differentiate between osteocytelike cells and was commonly used as an osteoblast model in various in vitro experiments [57]. The incubation was performed in a 24-well plate. For each well, $1.5 \mathrm{~mL}$ of culture medium was used. The cells were incubated for $24 \mathrm{~h}$ under cell culture conditions $\left(37{ }^{\circ} \mathrm{C}, 90 \%\right.$ humidity, $\left.5 \% \mathrm{CO}_{2}\right)$. After $24 \mathrm{~h}$, medium cells were removed and spotted with SAOS-2 lines plated (50,000 cells/well) onto a 24-well plate containing the test claim. After $48 \mathrm{~h}$ of cell culture in the control well, approximately $80 \%$ confluence was achieved and the experiment was terminated. Presented results were obtained during three independent experiments. After $1 \mathrm{~h}, 2 \mathrm{~mL}$ of culture medium were added to the culture and incubated under the same conditions for another $24 \mathrm{~h}$. Counters of targeted, live and necrotic cards were evaluated with attached confocal microscopes using propidium iodide MitoTracker ${ }^{\circledR}$ marker green, staining active mitochondria. This marker is located in the mitochondrial range from the width of the mitochondrial membrane. The propidium iodide test is one of the common methods of cytotoxicity testing. To determine mitochondria, cells are incubated with MitoTracker ${ }^{\circledR}$ probes, which passively diffuse across the plasma membrane and accumulate in active mitochondria. After labeling their mitochondria, the cells can be treated with an aldehyde-based fixer when used, which must be fixed to allow further processing of the samples. Available MitoTracker ${ }^{\circledR}$ probes are also retained after permeabilization with some detergents during the step stages. Propidium iodine penetrates inside the cell only when using cell membrane continuity. The dye does not penetrate into living cells, but in dead cells (when the membrane is permanently damaged and there is a loss of potential between the outer and inner side of the membrane), it penetrates inside, staining the cytoplasm or/and the nucleus. Propidium iodine penetrates inside the dead cells and intercalates with the nucleic acids, showing red fluorescence. The samples were stained with a solution $(1 \mathrm{mg} / \mathrm{mL})$ of propidium iodide for $5 \mathrm{~min}$ and then sluiced in PBS (phosphate buffer). Propidium iodine dyes damaged cells red by nucleating with nucleic acids. The more excitation of iodide, the greater the likelihood that cells located on the surface of the biomaterial were dead.

\subsubsection{Lactate Dehydrogenase}

Lactate dehydrogenase (abbreviated as LDH) is an enzyme that catalyzes the conversion of lactate to pyruvate (in the presence of $\mathrm{NAD}^{+}$), and vice versa (pyruvate to lactate in the presence of NADH). It is an enzyme found in all cells and body fluids. LDH measurement was carried out in culture fluid supernatants after $48 \mathrm{~h}$ of SAOS-2 cell culture. High activity of LDH correlates with cell damage and is used as a marker of injury and disease [58]. Measurement was carried out using a COBAS INTEGRA 400 PLUS appa- 
ratus from ROCHE. The results obtained are given in so-called Wróblewski units [59] or international units $(\mathrm{U})$.

4.2.5. Analysis of the Surface Interaction of Coatings with Selected Strains of Bacteria and Fungi

The examined biomaterials were incubated respectively with "cubes" of $15 \mathrm{~mL}$ of a 24-h culture of Pseudomonas aeruginosa, Streptococcus pyogenes, and Candida albicans and "circles" of $4 \mathrm{~mL}$ of a 24-h culture of Pseudomonas aeruginosa, Streptococcus pyogenes, and Candida albicans. The strains were grown on the following media:

- $\quad$ Pseudomonas aeruginosa $\left(\mathrm{ATCC}^{\circledR} 27,853^{\mathrm{TM}}\right.$ ): TSA medium, cultivation at $37^{\circ} \mathrm{C}$; composition of the substrate: TSA $40 \mathrm{~g}$ per $1000 \mathrm{~mL}$ MP water; sterilization: autoclave $1 \mathrm{~h}$, $121^{\circ} \mathrm{C}$.

- $\quad$ Streptococcus pyogenes Rosenbach (ATCC ${ }^{\circledR} 19,615^{\mathrm{TM}}$ ): TSA + blood mutant, culture at $37^{\circ} \mathrm{C}$; composition of the substrate: TSA $40 \mathrm{~g}$ per $1000 \mathrm{~mL}$ MP water, sheep blood $50 \mathrm{~mL}$ per $1000 \mathrm{~mL}$ medium (enriched the medium and allowed hemolytic reactions). This was the composition of media dedicated to the culture of streptococci (identified as alpha- or beta-hemolytic, depending on the appearance of the colony on this medium); added after sterilization (autoclave $1 \mathrm{~h}, 121^{\circ} \mathrm{C}$ ).

- Candida albicans: medium, broth + sugar; composition of the medium: ordinary broth$13 \mathrm{~g}$ per $1000 \mathrm{~mL}$ of MP water; glucose-20 g per $1000 \mathrm{~mL}$ of medium; sterilization: autoclave $1 \mathrm{~h}, 121^{\circ} \mathrm{C}$.

The biomaterials were rinsed with a $3.5 \%$ aqueous solution of paraformaldehyde, three times. The viability of microorganisms on the tested biomaterials was tested by staining the samples with a solution $(1 \mathrm{mg} / \mathrm{mL})$ of propidium iodide for $5 \mathrm{~min}$, followed by rinsing with PBS.

4.2.6. Test for Antimicrobial Activity of Biomaterials According to ISO 22,196 (JIS Z 2801 Test for Antimicrobial Activity of Plastics)

To analyze the microbiological properties of the coatings according to ISO 22196, the samples were cut into $5 \times 5 \mathrm{~cm}$ pieces and inoculated with a bacterial suspension of the units, forming a colony of approximately $2.5 \times 10^{5}-1.0 \times 10^{6} \mathrm{~mL}^{-1}$. The Staphylococcus aureus (ATCC ${ }^{\circledR} 6538 \mathrm{P}^{\mathrm{TM}}$ ) strain was selected for the study. Samples were incubated for $24 \mathrm{~h}$ at $95 \%$ relative humidity and $37^{\circ} \mathrm{C}$. During incubation, the bacterial suspension was covered with a $4 \times 4 \mathrm{~cm}$ PET (polyethylene terephthalate) film. The volume of bacterial suspension used thoroughly moistened the $4 \times 4 \mathrm{~cm}$ film. After an incubation period, the biomaterial, together with the culture and foil, was transferred to $5 \mathrm{~mL}$ PBS buffer $(10 \mathrm{mM}, \mathrm{pH}=7)$ and then sonicated for $5 \mathrm{~min}$ to accurately recover bacterial cells from the surface. To obtain a homogeneous bacterial suspension, the sample was mixed (Vortex device). The next stage of the research was the preparation of a number of dilutions of cultures in the sterile plates-type 96 with MaxiSorp. From each dilution, 10 microliters of culture were inoculated on casein soy agar (CSA) solid base. Agar plates were incubated for $24 \mathrm{~h}$ at $37^{\circ} \mathrm{C}$. To determine the initial number of bacteria, the microorganisms were counted after being applied to the biomaterial and quickly washed away from its surface. An antibacterial activity index $(R)$ was calculated in accordance with ISO 22,196 as follows:

$$
R=U_{t}-A_{t}
$$

In the formula, $R$ is the antibacterial activity index, $U_{t}$ is the logarithm of the number of viable cells recovered from untreated specimens after $24 \mathrm{~h}$ of incubation, and $A_{t}$ is the logarithm of the number of viable cells recovered from treated specimens after $24 \mathrm{~h}$ of incubation.

\section{Conclusions}

The study indicates that $\mathrm{Ti} / \mathrm{Ti}_{x} \mathrm{~N}$ coatings implanted with Ag nanoparticles significantly inhibit the growth of selected microorganisms and reduce the adhesion to the 
material surface (as confirmed by Figures 5-7). Additionally performed tests showed no significant cytotoxicity (Figures 3 and 4 ) to the osteosarcoma (SAOS-2) cells. The results of performed experiments indicate that $\mathrm{Ti} / \mathrm{Ti}_{\mathrm{x}} \mathrm{N}$ multilayer coatings implanted with $\mathrm{Ag}$ nanoparticles should improve bio-compatible properties of surgical spinal implants, and in effect, reduce the number of SSIs observed after spine surgeries.

Author Contributions: Concept of the design and microbiological analysis, K.K.; concept of the design and confocal microscopy analysis of cell-material interactions, R.M.; scanning electron microscopy analysis, A.S.; mechanical analysis, M.K. (Marcin Kot); industrial partner-idea of the aim, M.D.; microstructure analysis, Ł.M.; writing—review \& editing, A.B. and M.K. (Magdalena Kopernik); consultations, M.K. (Magdalena Kopernik); concept of the surface modification, J.M.L. All authors have read and agreed to the published version of the manuscript.

Funding: The work was supported by Grant M-ERA.NET M-ERA.NET/2015/02/2016; Antibacterial optimization of high-strength, severe-plastic-deformed titanium alloys for spinal implants and surgical tools from the National Center of Science and Development.

Institutional Review Board Statement: Not applicable.

Informed Consent Statement: Not applicable.

Data Availability Statement: The data presented in this study are available on request from the corresponding author.

Conflicts of Interest: The authors declare that they have no known competing financial interests nor personal relationships that could have appeared to influence the work reported in this paper.

Sample Availability: Samples of the compounds are available from the authors.

\section{References}

1. Romanò, C.L.; Scarponi, S.; Gallazzi, E.; Romanò, D.; Drago, L. Antibacterial coating of implants in orthopaedics and trauma: A classification proposal in an evolving panorama. J. Orthop. Surg. Res. 2015, 1, 157. [CrossRef] [PubMed]

2. Mazza, M.G. The physics of biofilms-an introduction. J. Phys. D 2016, 49, 203001. [CrossRef]

3. Souza, J.G.; Bertolini, M.M.; Costa, R.C.; Nagay, B.E.; Dongari-Bagtzoglou, A.; Barão, V.A. Targeting implant-associated infections: Titanium surface loaded with antimicrobial. iScience 2020, 24, 102008. [CrossRef] [PubMed]

4. McCarthy, H.; Rudkin, J.K.; Black, N.S.; Gallagher, L.; O'Neill, E.; O'Gara, J.P. Methicillin resistance and the biofilm phenotype in Staphylococcus aureus. Front. Cell. Infect. Microbiol. 2015, 5, 1. [CrossRef]

5. Lebeaux, D.; Ghigo, J.M.; Beloin, C. Biofilm-related infections: Bridging the gap between clinical management and fundamental aspects of recalcitrance toward antibiotics. Microbiol. Mol. Biol. Rev. 2014, 78, 510-543. [CrossRef] [PubMed]

6. Kulkarni Aranya, A.; Pushalkar, S.; Zhao, M.; LeGeros, R.Z.; Zhang, Y.; Saxena, D. Antibacterial and bioactive coatings on titanium implant surfaces. J. Biomed. Mater. Res. Part A 2017, 105, 2218-2227. [CrossRef] [PubMed]

7. Auñón, Á.; Esteban, J.; Doadrio, A.L.; Boiza-Sánchez, M.; Mediero, A.; Eguibar-Blázquez, D.; Cordero-Ampuero, J.; Conde, A.; Arenas, M.Á.; de-Damborenea, J.J.; et al. Staphylococcus aureus Prosthetic Joint Infection Is Prevented by a Fluorine- and Phosphorus-Doped Nanostructured Ti-6Al-4V Alloy Loaded with Gentamicin and Vancomycin. J. Orthop. Res. 2020, 38, 588-597. [CrossRef]

8. Mondal, S.; Dorozhkin, S.V.; Pal, U. Recent progress on fabrication and drug delivery applications of nanostructured hydroxyapatite. Wiley Interdiscip. Rev. Nanomed. Nanobiotechnol. 2018, 10, e1504. [CrossRef] [PubMed]

9. Zhang, B.; Braun, B.M.; Skelly, J.D.; Ayers, D.C.; Song, J. Significant Suppression of Staphylococcus aureus Colonization on Intramedullary Ti6Al4V Implants Surface-Grafted with Vancomycin-Bearing Polymer Brushes. ACS Appl. Mater. Interfaces 2019, 11, 28641-28647. [CrossRef]

10. Silverman, S.M.; Moses, J.E.; Sharpless, K.B. Reengineering Antibiotics to Combat Bacterial Resistance: Click Chemistry [1,2,3]Triazole Vancomycin Dimers with Potent Activity against MRSA and VRE. Chemistry 2017, 23, 79-83. [CrossRef]

11. Nichol, T.; Callaghan, J.; Townsend, R.; Stockley, I.; Hatton, P.V.; Le Maitre, C.; Smith, T.J.; Akid, R. The antimicrobial activity and biocompatibility of a controlled gentamicin-releasing single-layer sol-gel coating on hydroxyapatite-coated titanium. Bone Jt. J. 2021, 103-B, 522-529. [CrossRef] [PubMed]

12. Kulkarni, M.; Mazare, A.; Gongadze, E.; Perutkova, Š.; Kralj-Iglič, V.; Milošev, I.; Schmuki, P.; Iglič, A.; Mozetič, M. Titanium nanostructures for biomedical applications. Nanotechnology 2015, 26, 062002. [CrossRef] [PubMed]

13. Sista, S.; Nouri, A.; Li, Y.; Wen, C.; Hodgson, P.D.; Pande, G. Cell biological responses of osteoblasts on anodized nanotubular surface of a titanium-zirconium alloy. J. Biomed. Mater. Res. Part A 2013, 101, 3416-3430. [CrossRef] [PubMed]

14. Vörös, P.; Dobrindt, O.; Perka, C.; Windisch, C.; Matziolis, G.; Röhner, E. Human osteoblast damage after antiseptic treatment. Int. Orthop. 2014, 38, 177-182. [CrossRef] 
15. Wang, S.; Yang, Y.; Li, W.; Wu, Z.; Li, J.; Xu, K.; Zhang, W.; Zheng, X.; Chen, J. Study of the Relationship Between ChlorhexidineGrafted Amount and Biological Performances of Micro/Nanoporous Titanium Surfaces. ACS Omega 2019, 4, 18370-18380. [CrossRef] [PubMed]

16. Sarkar, S.; Bhattacharjee, C.; Curcio, S. Studies on adsorption, reaction mechanisms and kinetics for photocatalytic degradation of CHD, a pharmaceutical waste. Ecotoxicol. Environ. Saf. 2015, 121, 154-163. [CrossRef]

17. Liu, L.; Wu, H.; Riduan, S.N.; Ying, J.Y.; Zhang, Y. Short imidazolium chains effectively clear fungal biofilm in keratitis treatment. Biomaterials 2013, 34, 1018-1023. [CrossRef]

18. Li, P.; Poon, Y.F.; Li, W.; Zhu, H.Y.; Yeap, S.H.; Cao, Y.; Qi, X.; Zhou, C.; Lamrani, M.; Beuerman, R.W.; et al. A polycationic antimicrobial and biocompatible hydrogel with microbe membrane suctioning ability. Nat. Mater. 2011, 10, 149-156. [CrossRef] [PubMed]

19. Nederberg, F.; Zhang, Y.; Tan, J.P.; Xu, K.; Wang, H.; Yang, C.; Gao, S.; Guo, X.D.; Fukushima, K.; Li, L.; et al. Biodegradable nanostructures with selective lysis of microbial membranes. Nat. Chem. 2011, 3, 409-414. [CrossRef]

20. Xu, Z.; Kim, S.K.; Yoon, J. Revisit to imidazolium receptors for the recognition of anions: Highlighted research during 2006-2009. Chem. Soc. Rev. 2010, 39, 1457-1466. [CrossRef]

21. Lee, S.H.; Jun, B.H. Silver Nanoparticles: Synthesis and Application for Nanomedicine. Int. J. Mol. Sci. 2019, 20, 865. [CrossRef]

22. O'Sullivan, C.; O'Neill, L.; O'Leary, N.D.; O'Gara, J.P.; Crean, A.M.; Ryan, K.B. Osteointegration, antimicrobial and antibiofilm activity of orthopaedic titanium surfaces coated with silver and strontium-doped hydroxyapatite using a novel blasting process. Drug Deliv. Transl. Res. 2021, 11, 702-716. [CrossRef] [PubMed]

23. Lovati, A.B.; Lopa, S.; Bottagisio, M.; Talò, G.; Canciani, E.; Dellavia, C.; Alessandrino, A.; Biagiotti, M.; Freddi, G.; Segatti, F.; et al. Peptide-Enriched Silk Fibroin Sponge and Trabecular Titanium Composites to Enhance Bone Ingrowth of Prosthetic Implants in an Ovine Model of Bone Gaps. Front. Bioeng. Biotechnol. 2020, 8, 563203. [CrossRef]

24. Slate, A.J.; Wickens, D.J.; El Mohtadi, M.; Dempsey-Hibbert, N.; West, G.; Banks, C.E.; Whitehead, K.A. Antimicrobial activity of Ti-ZrN/Ag coatings for use in biomaterial applications. Sci. Rep. 2018, 8, 1497. [CrossRef]

25. Sevencan, A.; Kartal Doyuk, E.; Köse, N. Silver ion doped hydroxyapatite-coated titanium pins prevent bacterial colonization. Jt. Dis. Relat. Surg. 2021, 32, 35-41. [CrossRef] [PubMed]

26. Waugh, D.G.; Toccaceli, C.; Gillett, A.R.; Ng, C.H.; Hodgson, S.D.; Lawrence, J. Surface Treatments to Modulate Bioadhesion: A Critical Review. Rev. Adhes. Adhes. 2016, 4, 69-103. [CrossRef]

27. Hussmann, B.; Johann, I.; Kauther, M.D.; Landgraeber, S.; Jäger, M.; Lendemans, S. Measurement of the silver ion concentration in wound fluids after implantation of silver-coated megaprostheses: Correlation with the clinical outcome. BioMed Res. Int. 2013, 2013, 763096. [CrossRef]

28. Whitehead, K.A.; Li, H.; Kelly, P.J.; Verran, J. The Antimicrobial Properties of Titanium Nitride/Silver Nanocomposite Coatings. J. Adhes. Sci. Technol. 2011, 25, 2299-2315. [CrossRef]

29. Wojcieszak, D.; Mazur, M.; Kaczmarek, D.; Mazur, P.; Szponar, B.; Domaradzki, J.; Kepinski, L. Influence of the surface properties on bactericidal and fungicidal activity of magnetron sputtered Ti-Ag and Nb-Ag thin films. Mater. Sci. Eng. C Mater. Biol. Appl. 2016, 62, 86-95. [CrossRef]

30. Huang, H.L.; Chang, Y.Y.; Lai, M.C.; Lin, C.R.; Lai, C.H.; Shieh, T.M. Antibacterial TaN-Ag coatings on titanium dental implants. Surf. Coat. Technol. 2010, 205, 1636-1641. [CrossRef]

31. Hsieh, J.H.; Yeh, T.H.; Li, C.; Chiu, C.H.; Huang, C.T. Antibacterial properties of TaN-(Ag,Cu) nanocomposite thin films. Vaccum 2013, 87, 160-163. [CrossRef]

32. Marciano, F.R.; Bonetti, L.F.; Mangolin, J.F.; Da-Silva, N.S.; Corat, E.J.; Trava-Airoldi, V.J. Investigation into the antibacterial property and bacterial adhesion of diamond-like carbon films. Vaccum 2011, 85, 662-666. [CrossRef]

33. Lackner, J.M.; Waldhauser, W. Inorganic PVD and CVD Coatings in Medicine-A Review of Protein and Cell Adhesion on Coated Surfaces. J. Adhes. Sci. Technol. 2010, 24, 925-961. [CrossRef]

34. Inal, K.; Lackner, J.M.; Waldhauser, W.; Gümüş, S.; Polat, S.; Dalçik, H. Antibacterial Osseoconductive Thin Film for Implant. Turkish Patent EP3220969A1, 17 November 2014.

35. Syromotina, D.S.; Surmeneva, M.A.; Gorodzha, S.N.; Pichugin, V.F.; Ivanova, A.A.; Grubova, I.Y.; Kravchuk, K.S.; Gogolinskii, K.V.; Prymak, O.; Epple, M.; et al. Physical-Mechanical Characteristics of RF Magnetron Sputter-Deposited Coatings Based on SilverDoped Hydroxyapatite. Russ. Phys. J. 2014, 56, 1198-1205. [CrossRef]

36. Liou, J.W.; Chang, H.H. Bactericidal effects and mechanisms of visible light-responsive titanium dioxide photocatalysts on pathogenic bacteria. Arch. Immunol. Ther. Exp. 2012, 60, 267-275. [CrossRef]

37. Yue, C.; Kuijer, R.; Kaper, H.J.; van der Mei, H.C.; Busscher, H.J. Simultaneous interaction of bacteria and tissue cells with photocatalytically activated, anodized titanium surfaces. Biomaterials 2014, 35, 2580-2587. [CrossRef] [PubMed]

38. Xu, L.C.; Siedlecki, C.A. Protein adsorption, platelet adhesion, and bacterial adhesion to polyethylene-glycol-textured polyurethane biomaterial surfaces. J. Biomed. Mater. Res. B Appl. Biomater. 2017, 105, 668-678. [CrossRef] [PubMed]

39. Lih, E.; Choi, S.G.; Ahn, D.J.; Joung, Y.K.; Han, D.K. Optimal conjugation of catechol group onto hyaluronic acid in coronary stent substrate coating for the prevention of restenosis. J. Tissue Eng. 2016, 7, 2041731416683745. [CrossRef]

40. Zhao, L.; Hu, Y.; Xu, D.; Cai, K. Surface functionalization of titanium substrates with chitosan-lauric acid conjugate to enhance osteoblasts functions and inhibit bacteria adhesion. Colloids Surf. B Biointerfaces 2014, 119, 115-125. [CrossRef] [PubMed] 
41. Li, M.; Aveyard, J.; Fleming, G.; Curran, J.M.; McBride, F.; Raval, R.; D'Sa, R.A. Nitric Oxide Releasing Titanium Surfaces for Antimicrobial Bone-Integrating Orthopedic Implants. ACS Appl. Mater. Interfaces 2020, 12, 22433-22443. [CrossRef]

42. Peng, Z.; Ao, H.; Wang, L.; Guo, S.; Tang, T. Quaternised chitosan coating on titanium provides a self-protective surface that prevents bacterial colonisation and implant-associated infections. RSC Adv. 2015, 5, 54304-54311. [CrossRef]

43. Arciola, C.R.; Visai, L.; Testoni, F.; Arciola, S.; Campoccia, D.; Speziale, P.; Montanaro, L. Concise survey of Staphylococcus aureus virulence factors that promote adhesion and damage to peri-implant tissues. Int. J. Artif. Organs 2011, 34, 771-780. [CrossRef]

44. Feuillie, C.; Vitry, P.; McAleer, M.A.; Kezic, S.; Irvine, A.D.; Geoghegan, J.A.; Dufrêne, Y.F. Adhesion of Staphylococcus aureus to Corneocytes from Atopic Dermatitis Patients Is Controlled by Natural Moisturizing Factor Levels. Mbio 2018, 9, e01184-17. [CrossRef]

45. Foster, T.J. The remarkably multifunctional fibronectin binding proteins of Staphylococcus aureus. Eur. J. Clin. Microbiol. Infect. Dis. 2016, 35, 1923-1931. [CrossRef]

46. Eick, S.; Kindblom, C.; Mizgalska, D.; Magdon, A.; Jurczyk, K.; Sculean, A.; Stavropoulos, A. Adhesion of Porphyromonas gingivalis and Tannerella forsythia to dentin and titanium with sandblasted and acid etched surface coated with serum and serum proteins-An in vitro study. Arch. Oral Biol. 2017, 75, 81-88. [CrossRef]

47. Arciola, C.R.; Campoccia, D.; Ravaioli, S.; Montanaro, L. Polysaccharide intercellular adhesin in biofilm: Structural and regulatory aspects. Front. Cell. Infect. Microbiol. 2015, 5, 7. [CrossRef] [PubMed]

48. Kaba, S.I.; Egorova, E.M. In vitro studies of the toxic effects of silver nanoparticles on HeLa and U937 cells. Nanotechnol. Sci. Appl. 2015, 8, 19-29. [CrossRef] [PubMed]

49. Rice, K.C.; Bayles, K.W. Molecular Control of Bacterial Death and Lysis. Microbiol. Mol. Biol. Rev. 2008, 72, 85-109. [CrossRef] [PubMed]

50. Donlan, R.M. Biofilms and device-associated infections. Emerg. Infect. Dis. 2001, 7, 277-281. [CrossRef] [PubMed]

51. Khatoon, Z.; McTiernan, C.D.; Suuronen, E.J.; Mah, T.F.; Alarcon, E.I. Bacterial biofilm formation on implantable devices and approaches to its treatment and prevention. Heliyon 2018, 4, e01067. [CrossRef]

52. Elbehiry, A.; Al-Dubaib, M.; Marzouk, E.; Moussa, I. Antibacterial effects and resistance induction of silver and gold nanoparticles against Staphylococcus aureus -induced mastitis and the potential toxicity in rats. MicrobiologyOpen 2019, 8, e00698. [CrossRef] [PubMed]

53. Hosny, A.E.; Rasmy, S.A.; Aboul-Magd, D.S.; Kashef, M.T.; El-Bazza, Z.E. The increasing threat of silver-resistance in clinical isolates from wounds and burns. Infect. Drug Resist. 2019, 12, 1985-2001. [CrossRef] [PubMed]

54. Major, R.; Kowalczyk, P.; Surmiak, M.; Łojszczyk, I.; Podgórski, R.; Trzaskowska, P.; Ciach, T.; Russmueller, G.; Kasperkiewicz, K.; Major, Ł.; et al. Patient specific implants for jawbone reconstruction after tumor resection. Colloids Surf. B Biointerfaces 2020, 193, 111056. [CrossRef] [PubMed]

55. Trembecka-Wójciga, K.; Kopernik, M.; Surmiak, M.; Major, R.; Gawlikowski, M.; Bruckert, F.; Kot, M.; Lackner, J.M. Effect of the mechanical properties of carbon-based coatings on the mechanics of cell-material interactions. Colloids Surf. B Biointerfaces 2021, 197, 111359. [CrossRef] [PubMed]

56. Kopernik, M.; Milenin, A.; Major, R.; Lackner, J.M. Identification of material model TiN using numerical simulation of nanoindentation test. Mater. Sci. Technol. 2011, 27, 604-616. [CrossRef]

57. Prideaux, M.; Wijenayaka, A.R.; Kumarasinghe, D.D.; Ormsby, R.T.; Evdokiou, A.; Findlay, D.M.; Atkins, G.J. SaOS2 osteosarcoma cells as an in vitro model for studying the transition of human osteoblasts to osteocytes. Calcif. Tissue Int. 2014, 95, 183-193. [CrossRef]

58. Zhao, L.Z.; Wang, H.R.; Huo, K.F.; Cui, L.Y.; Zhang, W.R.; Ni, H.W.; Zhang, Y.M.; Wu, Z.F.; Chu, P.K. Antibacterial nano-structured titania coating incorporated with silver nanoparticles. Biomaterials 2011, 32, 5706-5716. [CrossRef]

59. Wróblewski, F.; Ladue, J.S. Lactic Dehydrogenase Activity in Blood. Exp. Biol. Med. 1955, 90, 210-213. [CrossRef] 